\title{
Functional expression of muscarinic and purinoceptors in the urinary bladder of male and female rats and guinea pigs
}

\author{
Kate E. CREED ${ }^{1}$, Rhonda A. LoXLEY ${ }^{1}$ and Jacqueline K. PHILliPS ${ }^{1,2}$ \\ ${ }^{1}$ Faculty of Health Sciences, School of Veterinary and Biomedical Science, Murdoch \\ University, Perth, Australia; \\ ${ }^{2}$ Australian School of Advanced Medicine, Macquarie University, Sydney, Australia
}

Received May 10, 2010; Accepted June 19, 2010

\begin{abstract}
Purpose: The objectives of this study were to compare the functional expression of muscarinic and purinergic receptors in the urinary bladder of 2 species, rat and guinea pig under comparable experimental conditions; and to test whether the receptors in males and females differ. Methods: Reverse transcription-polymerase chain reaction (RT-PCR) techniques were used to identify gene expression profiles in bladder smooth muscle (total $\mathrm{n}=8$ rats, 7 guinea pigs) and mechanical responses to nerve stimulation and applied acetylcholine $(\mathrm{ACh})$ in the presence of specific antagonists were used to identify functional receptor sub-types (total $n=12$ rats, 16 guinea pigs). Results: RT-PCR indicated that M2 and $\mathrm{M} 3$ were the predominant muscarinic receptor genes in both the male and female rat and guinea pig bladders. The phasic component of the nerve-induced contraction was greater in guinea pigs vs. rats. The tonic component and the $\mathrm{ACh}$ response were inhibited by the M3 receptor antagonist, darifenacin $\left(10^{-6} \mathrm{M}, P \leq 0.05\right)$, but not by the $\mathrm{M} 2$ receptor antagonist, methoctramine $\left(10^{-5} \mathrm{M}\right)$. The antipurinergic drug $\alpha$, $\beta$-methylene ATP $\left(5 \times 10^{-5}\right.$ M) caused a significant reduction in the amplitude of the phasic response to nerve stimulation in all groups, and this effect was significantly greater in male $v s$. female rats. mRNA for the purinergic P2X1, P2X2, P2X4, P2X5 and P2X7 receptors was detected in both male and female rats, whereas $\mathrm{P} 2 \mathrm{X} 3$ and $\mathrm{P} 2 \mathrm{X} 6$ were inconsistently detected in male rats. The P2X1 purinoceptor antagonist pyridoxal-5'-phosphate-6-(2'-naphthylazo-6'-nitro4', 8'-disulphonate) (PPNDS), only inhibited nerve induced contractions at high concentrations (up to $10^{-4} \mathrm{M}$ ). Conclusions: While only minor functional differences were documented in cholinergic and purinergic bladder contractile responses between male and female animals, and between rats and guinea pigs, data such as presented in this study are critical in determining how relative functional contributions may change in the diseased state, providing valuable information towards new treatment options.
\end{abstract}

Key words: acetylcholine, ATP, bladder, smooth muscle, receptor 


\section{Introduction}

During micturition, bladder contraction is brought about by activity of the pelvic nerves. In most mammals the initial (phasic) contraction is thought to result from adenosine triphosphate (ATP), released by parasympathetic nerves, acting on P2X purinoceptors on the smooth muscle cell membrane, while prolonged contraction results from the action of acetylcholine (ACh) which acts on muscarinic receptors on the membrane (Burnstock, 2009; Callahan and Creed, 1986). In humans, the purinoceptors are of minor importance in the healthy bladder but play some role in overactive bladders (Bayliss et al., 1999). There is no classical functional inhibition although nerves containing nitric oxide and noradrenaline have been identified in the bladder. These may act in-vivo on other structures in the bladder wall such as sensory nerves or the urothelium.

Of the 5 muscarinic receptor subtypes (M1-M5) that may mediate functional responses to ACh, M2 and M3 have been identified pharmacologically on the smooth muscle membrane of the bladder (Eglen et al., 1996). Whereas the M2 subtype is most common, the M3 is functionally more important in producing contraction of isolated bladder, with M2 thought to act by inhibiting beta-adrenergic relaxation in-vivo (Hegde et al., 1997). This is supported by the observation that contractions of bladders from knockout mice without M3 receptors are greatly reduced (Matsui $e t$ al., 2000; Igawa et al., 2004). Whereas studies with immunological and Northern Blot techniques have failed to reveal M1 and M4 subtypes, the genes responsible for synthesis of the receptor subtypes M1-M4 have been identified by reverse transcription-polymerase chain reaction (RTPCR) on whole extracts of rat bladder wall (Braverman et al., 1998a). An increase in bladder smooth muscle M3 receptor mRNA expression has recently been demonstrated in rats with bladder outlet obstruction (Kim et al., 2008).

Rapid responses to ATP are mediated by purinergic P2X receptors, which have been classified into 7 subtypes, which come together to form non-selective cation channels (Khakh et al., 2001). Variable profiles of expression have been detected using different methods in the bladder including from human tissue (O'Reilly et al., 2001; O'Reilly et al., 2002). Contraction is thought however to be mediated primarily via P2X1 receptors, since bladder contraction does not occur in mice having a P2X1 receptor deficiency (Vial and Evans, 2000).

Although there are differences in the incidence and characteristics of overactive bladder in humans (Cheung et al., 2009), and male but not female M3 receptor knock-out mice have difficulty urinating (Matsui et al., 2000), comparisons of the differential contractile bladder responses to nerve stimulation in males and females under directly comparable experimental conditions are warranted. Furthermore, since results from a number of different species are often compared, responses in two species, rats and guinea pigs, were assessed to see whether it is valid to extrapolate from one species to another.

In the present experiments, we therefore used both molecular and pharmacological techniques to assess both the relative incidence and functional expression of receptor subtypes on detrusor muscle, and aimed to determine whether differences exist between males and females. RT-PCR techniques were used to identify which genes were present and then a combination of nerve stimulation and agonist/antagonist applications were used to identify the functional receptor subtypes responsible for bladder contraction. 


\section{Methods}

\section{Animals}

Young adult tricolour guinea pigs ( $\sim 400 \mathrm{~g}$ body weight) and Wistar rats ( $\sim 250 \mathrm{~g}$ body weight) of both sexes were used. All experiments were carried out with the approval of the Animal Ethics Committee of Murdoch University, Western Australia. The stage the females were at in the oestrus cycle was not identified. After being subdued in $80 \% \mathrm{CO}_{2}$ in $\mathrm{O}_{2}$, the animals were killed by exsanguinations and the abdomen was opened in the mid-line. The urinary bladder was removed into ice-cold 0.1 M phosphate buffer $\mathrm{pH}$ 7.4. The external connective tissue was removed, the bladder was opened by a mid-dorsal incision and the urothelium stripped.

\section{Total RNA extraction}

For rat tissue (4 male and 4 female), bladder muscle strips were cut into pieces $1-2 \mathrm{~mm}$ square. RNA was extracted by the Promega RNagents ${ }^{\circledR}$ Total RNA Isolation System (Promega, Madison, WI, USA) following the manufacturer's instructions. Briefly, the tissue was transferred to an ice-cold 1:1 solution of denaturing agent and phenol: chloroform: isoamyl alcohol (Promega), and homogenised in a Tenbroeck glass tissue grinder (Wheaton Science Products, Millville, NJ, USA). RNA was precipitated from the extraction solution with isopropanol, $20 \mathrm{U}$ glycogen (Roche Molecular Biochemicals, Mannheim, Germany) and $0.3 \mathrm{M}$ sodium acetate ( $\mathrm{pH} 4.0$ ). After centrifugation, the RNA pellet was washed in $70 \% v / v$ ethanol then resuspended in $20 \mu$ l RNasefree water.

For guinea pig bladder ( 3 males; 4 females), RNA was extracted with the MasterPure ${ }^{\mathrm{TM}}$ RNA Purification Kit (Epicentre, Madison, WI, USA). After stripping and cutting, the pieces were transferred to an ice-cold lysis solution containing $50 \mu$ g Proteinase K (MasterPure ${ }^{\mathrm{TM}}$ ) per $300 \mu \mathrm{L}$, and homogenized as described above. Debris from the solution was precipitated with MPC Protein Precipitation Reagent (MasterPure ${ }^{\mathrm{TM}}$ ) and then RNA was precipitated with isopropanol and the pellet washed in $70 \% v / v$ ethanol before resuspension in $20 \mu \mathrm{L}$ of RNase-free water.

For both rat and guinea pig tissue, contaminating genomic DNA was removed with RQ1 RNase-free DNase $1\left(1 \mathrm{U}\right.$, Promega) at $37^{\circ} \mathrm{C}$ for $20 \mathrm{~min}$ in a final volume of $100 \mu \mathrm{L}$, containing 40 $\mathrm{U}$ of RNasin Rnase inhibitor (Promega), $40 \mathrm{mM}$ Tris, $\mathrm{pH} 8.0,10 \mathrm{mM} \mathrm{MgCl}, 1 \mathrm{mM} \mathrm{CaCl}_{2}$ and 10 $\mathrm{mM}$ dithiothrietol (DTT). For the guinea pig RNA samples this process was repeated to ensure complete removal of genomic DNA. RNA was re-extracted with phenol: chloroform: isoamyl alcohol and Phase Lock Gel Tubes (Eppendorf, Brinkman Instruments, New York, USA) and precipitated in $100 \%$ ethanol with $20 \mathrm{U}$ glycogen (Roche) and $0.3 \mathrm{M}$ sodium acetate at pH 4.0. RNA concentration was assayed on a UV spectrometer (Shimadzu UV Mini 1240, Shimadzu Corp, NSW, Australia).

\section{Reverse transcription}

To produce a complementary DNA pool (cDNA), $5 \mu \mathrm{g}$ of RNA was reverse transcribed in a 50 $\mu \mathrm{L}$ final volume by using Superscript II or Superscript III (100-200 U, Invitrogen, Carlsbad, CA, USA) in $1 \times \mathrm{RT}$ buffer $\mathrm{pH} 8.3$ (Invitrogen), with $2.5 \mathrm{ng} / \mu \mathrm{L}$ random primers (Invitrogen), $1 \mathrm{mM} \mathrm{2}$ deoxynucleoside-s'triphosphate (dNTPs, Invitrogen), 5-10 mM DTT (Invitrogen), and 20-40 U 
Table 1. Primers used to detect guinea pig muscarinic receptors

\begin{tabular}{|c|c|c|c|c|}
\hline Gene & Primer Sequence $^{\mathrm{a}}$ & $\begin{array}{l}\text { Annealing Temp } \\
\qquad\left({ }^{\circ} \mathrm{C}\right)^{\mathrm{b}}\end{array}$ & $\begin{array}{l}\text { Product Length } \\
(\mathrm{bp})^{\mathrm{c}}\end{array}$ & Accession number ${ }^{d}$ \\
\hline GPM1 & $\begin{array}{l}\text { 5'-GTCAGCCCCAACATCACCATTC-3' } \\
\text { 5'-ATAGTCCAGAGCCAGCCAGAGG-3' }\end{array}$ & 57 & 294 & [GenBank:AY072058] \\
\hline GPM2 & $\begin{array}{l}\text { 5'-TCTCGAGCCAGCAAGAGCAGGAT-3' } \\
\text { 5'-GCCAGCAGAATAGCCAAGATT-3' }\end{array}$ & 55 & 557 & [GenBank:AY072059] \\
\hline GPM3 & $\begin{array}{l}\text { 5'-TCTTTTGTCCTTTGGGCTCCTG-3' } \\
\text { 5'-GGCTTTGCTGCTGTAGTTCATAGC-3' }\end{array}$ & 61 & 313 & [GenBank:AY072060] \\
\hline GPM4 & $\begin{array}{l}\text { 5'-AGTGCTTCATCCAGTTCCTGTCCA-3' } \\
\text { 5'-CACACTCATTGCCCGTCTGCTTCG-3' }\end{array}$ & 62 & 510 & [GenBank:AY072061] \\
\hline GPM5 & $\begin{array}{l}\text { 5'-GCAGCTGTGTCTGCAGTGGTCAGC-3' } \\
\text { 5'-CTGGAGCTCAGCCAGATCTTTGGT-3' }\end{array}$ & 58 & 594 & [GenBank:AY072062] \\
\hline
\end{tabular}

a, Sequence information for primers used for polymerase chain reaction. ${ }^{\text {b }}$, Optimised annealing temperature for individual primer pairs ${ }^{\mathrm{c}}$, Expected PCR product length for amplicon. ${ }^{\mathrm{d}}$, GenBank accession number for guinea pig mRNA sequence from which primers were designed.

Rnasin Rnase inhibitor (Promega) at $50^{\circ} \mathrm{C}$ for $45 \mathrm{~min}$ and then $55^{\circ} \mathrm{C}$ for $30 \mathrm{~min}$. The RT enzyme was then heat-inactivated $\left(90^{\circ} \mathrm{C}\right.$ for $\left.5 \mathrm{~min}\right)$. Samples, in which RT enzyme or starting RNA was omitted, were also forwarded for PCR as negative control samples. From the cDNA pool generated, $2 \mu \mathrm{L}$ was used for each PCR reaction.

\section{PCR}

Polymerase chain reactions were performed with primers specific for purinergic P2X1-P2X7 receptors in rat and muscarinic M1-M5 receptors in rat and guinea pig. Details for primers used on rat tissue have been published previously (Drescher et al., 1992; Phillips et al., 1996; Phillips et al., 1998). Primers for the guinea pig muscarinic receptors were designed from published sequences (Genebank accession numbers AY072058-AY072062), with Oligo 4.04 Primer Analysis Software (National Biosciences Inc., Plymouth, MN, USA). See Table 1 for primer details and PCR conditions. Primers for guinea pig purinoceptors were not designed due to lack of complete sequence information for all $\mathrm{P} 2 \mathrm{X}$ receptor subtypes.

PCR reactions (35-40 cycles) were performed on a Corbett Palm Cycler Version 2.0 (Corbett Research, Montlake, NSW Australia) in a $25 \mu \mathrm{L}$ volume containing 0.625 U DNA polymerase (AmpliTaq Gold; Roche Molecular Systems Inc., Branchburg, NJ, USA), $1 \times$ PCR gold buffer at pH 8.0, $0.25 \mathrm{mM}$ dNTPs (each Invitrogen), 2.0 or $2.5 \mathrm{mM} \mathrm{MgCl}_{2}$ and $200 \mathrm{nM}$ of each primer. The first cycle consisted of $10 \mathrm{~min}$ at $94^{\circ} \mathrm{C}$ to activate the enzyme. Subsequent cycles consisted of denaturation at $94^{\circ} \mathrm{C}$ for $45 \mathrm{sec}$, annealing at $54-67^{\circ} \mathrm{C}$ for $1 \mathrm{~min}$, and extension at $72^{\circ} \mathrm{C}$ for $90 \mathrm{sec}$. The final extension lasted $5 \mathrm{~min}$ at $72^{\circ} \mathrm{C}$. Positive control brain samples and negative controls as described were included.

Amplified fragments were separated on a $2 \%(w / v)$ agarose gel post-stained with ethidium bromide and viewed under UV light. Product size was confirmed by comparison with 100 bp DNA ladder (Promega).

\section{Mechanical recording}

For mechanical recording, data was obtained from a total of $n=6$ male and $n=6$ female rats and 
$\mathrm{n}=8$ male and $\mathrm{n}=8$ female guinea pigs (not all experiments were performed on tissue from every animal). After removal of the urothelium and mucosa, full thickness longitudinal strips $(2 \times 10$ $\mathrm{mm}$ ) of detrusor muscle were prepared from each bladder and set up in a $10 \mathrm{ml}$ organ bath filled with modified Krebs solution at $36^{\circ} \mathrm{C}$ with the following composition (mM): $\mathrm{NaCl} 120.0, \mathrm{KCl} 5.0$, $\mathrm{CaCl}_{2} 2.5, \mathrm{NaHCO}_{3} 25.0, \mathrm{MgSO}_{4}$ 1.0, $\mathrm{NaH}_{2} \mathrm{PO}_{4} 1.0$ and glucose 11.0 equilibrated with $5 \% \mathrm{CO}_{2}$ in $\mathrm{O}_{2}$ to give a $\mathrm{pH}$ of 7.4 .

The strips were passed through paired Ag ring electrodes and one end was attached by thread to a force transducer (FT.03, Grass, Boston, Mass, USA). The resting tension was adjusted to $1 \mathrm{~g}$ and contractions were recorded on a Grass polygraph recorder and Maclab for later analysis. The strips were equilibrated for one hour. Field stimulation of nerves was applied with pulses of $60 \mathrm{~V}$, $0.6 \mathrm{msec}$ for $6-10 \mathrm{sec}$. Frequencies of $1-50 \mathrm{~Hz}$ were used at the beginning of each experiment. We subsequently used 1,5 and $20 \mathrm{~Hz}$ to provide responses to low, medium and high frequencies. The phasic response was measured as the maximum contraction, which occurred $\sim 2$ sec after the beginning of stimulation. If stimulation was continued, the response was reduced and plateaued beyond $6 \mathrm{sec}$. The tonic response was therefore measured at the end of the $6 \mathrm{sec}$ stimulation period. Agonist drugs were added to the bath to achieve the concentration required and response recorded. Similarly, antagonist drugs were added to the bathing solution to give the concentration indicated and the stimulation was repeated after 30 mins equilibration.

Drugs used were acetylcholine chloride, ATP, atropine sulphate, methoctramine (M2 receptor antagonist), $\alpha, \beta$-methylene ATP ( $\alpha, \beta$-meth ATP), tetrodotoxin (TTX) and Pyridoxal-5'phosphate-6-(2'-naphthylazo-6'-nitro-4', 8'-disulphonate) (PPNDS) (Sigma, St Louis, Missouri, USA). Darifenacin (M3 receptor antagonist) was kindly donated by Pfizer (Sandwich, Kent, England). Dose-response curves were plotted to measure the effect of antagonists on increasing doses of $\mathrm{ACh}$ and on responses to nerve stimulation. The $\mathrm{pA}_{2}$ values were obtained by plotting $\mathrm{ED}_{50}$ against antagonist concentration. As only one mean value for each $\mathrm{ED}_{50}$ was obtained, an SEM is not provided.

\section{Statistical analysis}

Data represents a minimum of 5 to 7 animals for each group. Duplicate or triplicate reactions from an individual animal were averaged and reported $n$ values indicate animal numbers. Values are reported as mean \pm standard error of the mean (SEM). Statistical analysis was performed using a two-tailed Students $t$-test to compare responses between control and test condition, with significance set at $P \leq 0.05$. When multiple analyses were made, a Bonferroni correction was applied. Software utilised was either SPSS Statistical Package (SPSS Inc., IL, USA) or GraphPad Software (GraphPad Software, Inc. La Jolla, CA USA). Responses to electrical stimulation in the presence of either $\alpha, \beta$-meth ATP or PPNDS are presented as change relative to control (set to $=100 \%)$.

\section{Results}

\section{RT-PCR}

Expression of RNA for the muscarinic and purinoceptors is shown in Table 2. Of the 
Table 2. Expression of mRNA for muscarinic and purinergic receptors in rat and guinea pig bladder

\begin{tabular}{ccccc}
\hline Receptor subtype & Female rat & Male rat & Female guinea pig & Male guinea pig \\
\hline M1 & $+^{(2 / 4)}$ & $+^{(3 / 4)}$ & $+^{(1 / 4)}$ & $++^{(2 / 3)}$ \\
M2 & ++ & ++ & ++ & ++ \\
M3 & $+{ }^{(3 / 4)}$ & ++ & ++ & ++ \\
M4 & $+{ }^{(2 / 4)}$ & $+{ }^{(2 / 4)}$ & 0 & 0 \\
M5 & $+{ }^{(2 / 4)}$ & ++ & $+^{(2 / 4)}$ & 0 \\
P2X1 & ++ & ++ & - & - \\
P2X2 & ++ & ++ & - & - \\
P2X3 & $+{ }^{(3 / 4)}$ & 0 & - & - \\
P2X4 & ++ & ++ & - & - \\
P2X5 & ++ & ++ & - & - \\
P2X6 & ++ & $+{ }^{(2 / 4)}$ & - & - \\
P2X7 & ++ & ++ & - &
\end{tabular}

Crosses represent consistency by which PCR product was detected in each animal group by the specific primers. $[0]=$ never detected, $[+]=$ not detected all animals (number in brackets indicates number of animal tested positive/number of animals tested), $[++]=$ detected in every animal. $[-]$ not examined. $n=8$ rats ( 4 male, 4 female) and 7 guinea pigs ( 3 male, 4 female).

muscarinic receptors, M2 was most consistently detected across both species and sexes, while M3 was detected in all animals except for one female rat. Expression for M1, M4 and M5 was variable. For example M1 receptors were detected in all groups but not all animals within each group (5/8 rats and 3/7 guinea pigs), while M4 was never detected in guinea pigs and M5 was never detected in male guinea pigs. A gel illustrating detection of an example of muscarinic receptor mRNA from the guinea pig bladder is shown in Fig. 1 .

Analysis of PCR product for purinoceptor expression in the rat tissue indicated consistent detection of mRNA for P2X1, P2X2, P2X4, P2X5, and P2X7. P2X3 and P2X6 expression differed between male and female rats, with higher levels of both $\mathrm{P} 2 \mathrm{X} 3$ and $\mathrm{P} 2 \mathrm{X} 6$ expression in the females.

In 2 preliminary experiments (a male and a female rat), the urothelium was not removed and there was very high expression of P2X3, as evidenced by a significantly greater intensity and size of the PCR product, which was not seen in any of the other preparations, indicating successful removal of the urothelium in the other preparations.

No PCR product was seen when reverse transcriptase enzyme or RNA was omitted from reactions. The efficiency of all primer pairs was confirmed in brain tissue from corresponding species where an appropriately sized amplicon was strongly detected. All fragments corresponded to the predicted fragment size for each receptor subtype.

\section{Mechanical responses}

Strips from both species showed initial spontaneous activity but this decreased during the onehour equilibration period. Nerve stimulation produced contraction of the strips with a phasic maximal component followed by a tonic component at higher frequencies (Fig. 2A). At $20 \mathrm{~Hz}$ under control conditions the phasic response was close to maximum (Callahan and Creed, 1986) and was larger in guinea pig than rat (grouped data rat $2.53 \mathrm{~g} \pm 0.2 \mathrm{vs}$. guinea pig $5.28 \mathrm{~g} \pm 0.455, P \leq 0.05$, $\mathrm{n}=25)$ and was larger in male guinea pigs compared to female guinea pigs ( $6.39 \mathrm{~g} \pm 0.52 \mathrm{vs} .4 .18$ 


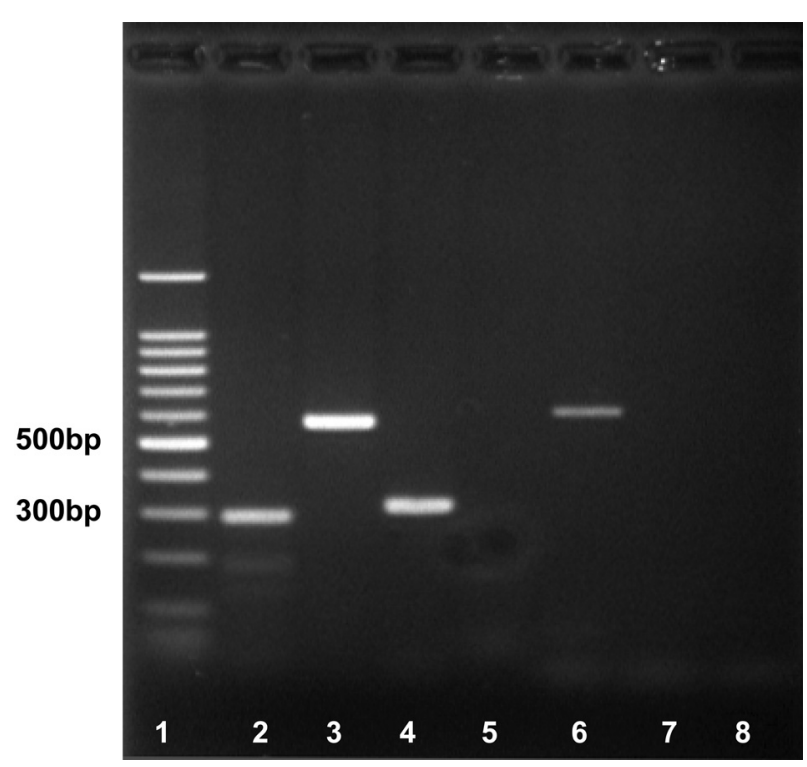

Fig. 1. Muscarinic receptor PCR products from guinea pig bladder. Agarose gel showing amplicons obtained from the bladder detrusor muscle of a female guinea pig using primers for muscarinic receptors M1-M5 designed against published guinea pig sequences. Lane 1: 100 base pair (bp) ladder. Lanes 2-6. PCR product was detected using the primers for M1, M2, M3 and M5 (lanes 2, 3, 4 and 6 at 294, 557, 313 and 594 bp, respectively). No product was detected for M4 but control experiments on cDNA extracted from guinea pig brain produced product of the predicted size $(510 \mathrm{bp})$. Lanes 7 and 8: Control samples taken through RT and PCR process in the absence of RT enzyme or cDNA, respectively, tested with the M2 primer pair.

$\mathrm{g} \pm 0.47, P \leq 0.05, \mathrm{n}=14$, Fig. $3 \mathrm{~A})$. The tonic response declined slightly during stimulation and returned rapidly to the baseline at the end of stimulation (Fig. 2A). There was no significant difference between species or sex in the tonic component (Fig. 3B).

Application of $\mathrm{ACh}$ produced dose dependent contraction with a maximum at $10^{-2} \mathrm{M}$ that was similar to the contraction produced by $\mathrm{KCl}(50 \mathrm{mM})$ and was well maintained while ACh remained in the bath. Taking the response to $3 \times 10^{-2} \mathrm{M} \mathrm{ACh}$ as $100 \%$, the $\mathrm{ED}_{50}$ calculated for male and female rats were less than for guinea pigs (Table 3). The response to $20 \mathrm{~Hz}$ field stimulation was smaller than the maximum response to ACh (20Hz:ACh \%; Table 3$)$. There was no significant difference between males and females of each species.

Application of ATP $\left(10^{-4} \mathrm{M}\right)$ produced small, inconsistent contractions that were transient. Application of $\alpha, \beta$-meth ATP $\left(5 \times 10^{-4} \mathrm{M}\right)$ contracted the bladder strips, producing large responses on first application (male rat $2.87 \pm 0.49 \mathrm{~g}$, female rat $1.94 \pm 0.88 \mathrm{~g}$, male guinea pig $3.01 \pm 1.37 \mathrm{~g}$, female guinea pig $2.33 \pm 1.61 \mathrm{~g}, \mathrm{n}=4-6)$. In the continued presence of $\alpha, \beta$-meth ATP, the tension was poorly maintained. Upon washout, the contraction returned to the base line over a 20 min period. Subsequent application of $\alpha, \beta$-meth ATP at $30 \mathrm{~min}$ or later, even after washing, produced a very small or no contraction. 


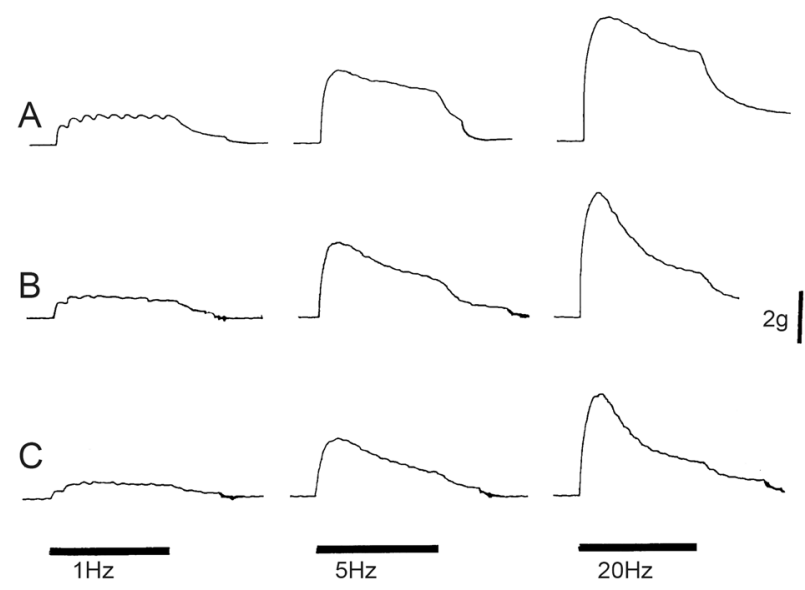

Fig. 2. Phasic and tonic components of nerve induced contractions. Responses to stimulation at 1,5 and $20 \mathrm{~Hz}$ of a detrusor muscle strip from female guinea pig under control conditions and in the presence of muscarinic receptor antagonists. Panel A shows a control response, illustrating the phasic response (peak amplitude) and the tonic contraction, recorded at the end of the stimulation period. Both increased in response to increased frequency of stimulation. The tonic response was reduced by darifenacin $\left(10^{-6} \mathrm{M}\right.$, Panel $\left.\mathrm{B}\right)$ and the further addition of atropine $\left(10^{-6} \mathrm{M}\right.$, Panel $\left.\mathrm{C}\right)$ produced only a slight further reduction. Field stimulation was applied for 6 seconds (bar lower panel). A 2-gram scale bar is shown to the right of the figure.

A

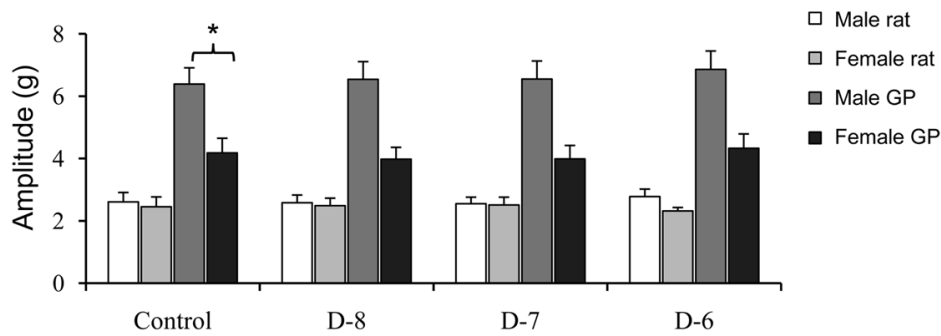

B

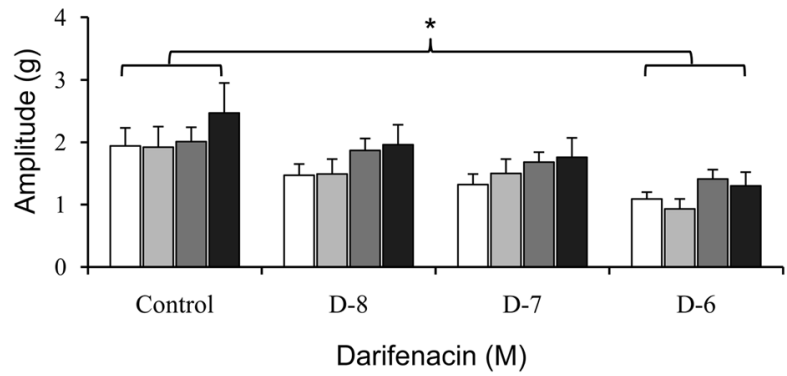

Fig. 3. Effect of M3 receptor antagonist on nerve induced contractions. Effect of the M3 muscarinic receptor antagonist, darifenacin, on nerve induced contractions of bladder strips. Histograms show mean amplitudes of both the phasic (Panel A) and tonic components (Panel B) of bladder strip contractions in male and female rats, and guinea pig (GP). Each point is the mean of 5-7 animals; bars are SEM. D-8, D-7 and D$6=$ darifenacin $10^{-8} \mathrm{M}, 10^{-7} \mathrm{M}$ and $10^{-6} \mathrm{M}$, respectively. *, Significantly different to indicated group $P \leq 0.05$. 
Table 3. Mechanical responses of bladder strips

\begin{tabular}{llccc}
\hline & $\begin{array}{c}\text { Male rat } \\
(\mathrm{n}=5)\end{array}$ & $\begin{array}{c}\text { Female rat } \\
(\mathrm{n}=6)\end{array}$ & $\begin{array}{c}\text { Male guinea pig } \\
(\mathrm{n}=7)\end{array}$ & $\begin{array}{c}\text { Female guinea pig } \\
(\mathrm{n}=7)\end{array}$ \\
\hline $\mathrm{ACh} \mathrm{ED}_{50}($ control $)$ & $3.24 \times 10^{-4} \mathrm{M}$ & $2.1 \times 10^{-4} \mathrm{M}$ & $4.7 \times 10^{-4} \mathrm{M}$ & $4.44 \times 10^{-4} \mathrm{M}$ \\
$20 \mathrm{~Hz}:$ ACh $3 \times 10^{-2} \mathrm{M}(\%)$ & $69.0 \pm 3.2$ & $66.4 \pm 5.0$ & $81.8 \pm 4.3$ & $83.4 \pm 6.1$ \\
$20 \mathrm{~Hz}$ Phasic $($ control $)$ & $2.61 \pm 0.30 \mathrm{~g}$ & $2.45 \pm 0.32 \mathrm{~g}$ & $6.39 \pm 0.52 \mathrm{~g}$ & $4.18 \pm 0.47 \mathrm{~g}$ \\
$20 \mathrm{~Hz}$ Tonic $($ control) & $1.95 \pm 0.29 \mathrm{~g}$ & $1.92 \pm 0.33 \mathrm{~g}$ & $2.01 \pm 0.23 \mathrm{~g}$ & $2.47 \pm 0.48 \mathrm{~g}$ \\
$20 \mathrm{~Hz}$ Phasic $\left(\mathrm{M} \mathrm{10} 0^{-5} \mathrm{M}\right)$ & $2.36 \pm 0.23 \mathrm{~g}$ & $2.46 \pm 0.27 \mathrm{~g}$ & $5.85 \pm 0.30 \mathrm{~g}$ & $3.87 \pm 0.15 \mathrm{~g}$ \\
$20 \mathrm{~Hz}$ Tonic $\left(\mathrm{M} \mathrm{10} 0^{-5} \mathrm{M}\right)$ & $1.40 \pm 0.20 \mathrm{~g}$ & $1.57 \pm 0.28 \mathrm{~g}$ & $2.17 \pm 0.19 \mathrm{~g}$ & $2.26 \pm 0.16 \mathrm{~g}$ \\
\hline
\end{tabular}

Mechanical responses of bladder strips from male and female rats and guinea pigs to applied acetylcholine $(\mathrm{ACh})$ or electrical stimulation $(20 \mathrm{~Hz})$ under control conditions and in the presence of the M2 receptor antagonist methoctramine $(\mathrm{M})$. The $\mathrm{ED}_{50}$ value for $\mathrm{ACh}$ was calculated taking the response to $3 \times 10^{-2} \mathrm{M} \mathrm{ACh}$ as $100 \%$. Calculated $\mathrm{n}$ values indicate animal number, derived from the average of duplicate or triplicate replicates from an individual animal. Values are reported as mean \pm standard error of the mean (SEM).

\section{Effects of antagonist drugs}

(i) Effect of muscarinic receptor antagonists on nerve induced responses

Methoctramine (M2 receptor antagonist) at $10^{-5} \mathrm{M}$ did not significantly reduce either the phasic or tonic response (Table 3). Darifenacin (M3 receptor antagonist) at concentrations of from $10^{-8}$ to $10^{-6} \mathrm{M}$ had no significant effect on the phasic response (Fig. 3A). However, the tonic component was reduced in all groups by Darifenacin at $10^{-6} \mathrm{M}(P \leq 0.05$, Fig. 2B, Fig. 3B). Addition of atropine $\left(10^{-6} \mathrm{M}\right)$ produced no further reduction (Fig. $\left.2 \mathrm{C}\right)$. In the presence of TTX $\left(10^{-6} \mathrm{M}\right)$, only a residual contraction occurred at 5 and $20 \mathrm{~Hz}$, indicating a negligible component of the response was due to direct stimulation of the muscle. Similar antagonism occurred in males and females.

(ii) Effect of antipurinergic drugs on nerve induced responses

$\alpha, \beta$-Meth ATP is believed to desensitise P2X1 and P2X3 purinoceptors (North, 2002). In our preparation, $\alpha, \beta$-meth ATP caused a significant reduction $(P \leq 0.05)$ in the amplitude of the phasic response to nerve stimulation in all groups. The response in male rats at $5 \mathrm{~Hz}$ in the presence of $5 \times 10^{-5} \mathrm{M} \alpha, \beta$-meth ATP was reduced to $26.0 \pm 2.6 \%$ of control while that in female rats was reduced to $41.31 \pm 5.82 \%$ ( $P \leq 0.05$ between males and females, $n=6$ per group). In male guinea pigs the response was reduced to $28.45 \pm 3.0 \%$, and in female guinea pigs to $22.6 \pm 7.2 \%$ of control ( $\mathrm{n}=6$ per group).

PPNDS, a selective P2X1 receptor antagonist (Lambrecht et al., 2000) had no direct effect on bladder strips. At $5 \times 10^{-5} \mathrm{M}$ it had no significant effect on the nerve-mediated response to $5 \mathrm{~Hz}$ on bladder strips from male or female rats $(98.67 \pm 1.5 \%$ and $90.57 \pm 3.08 \%, \mathrm{n}=6$, respectively). However, at $5 \times 10^{-4} \mathrm{M}$ a significant reduction $(P \leq 0.05)$ in response was seen for both male and female rats (male: $60.01 \pm 5.21 \%$, female: $68.6 \pm 5.8 \%$ of control, $\mathrm{n}=6$ per group). The guinea pig bladder muscle was also sensitive, with significant reductions of the phasic responses to $5 \mathrm{~Hz}$ to $69.9 \pm 3.1 \%$ of control for males and to $82.5 \pm 5.9 \%$ for females in the presence of $3 \times 10^{-5} \mathrm{M}$ PPNDS ( $\mathrm{n}=6$ per group) and to $51.8 \pm 3.5 \%$ for males and to $50.5 \pm 9.1 \%$ for females in the presence of $1 \times 10^{-4} \mathrm{M}$ PPNDS $(\mathrm{n}=6 ; P \leq 0.05)$. Similar results were recorded for other frequencies of stimulation (data not presented). When comparing the response between sexes, together the $\alpha, \beta$-meth ATP and PPNDS data suggest a greater purinergic contribution to the 
A

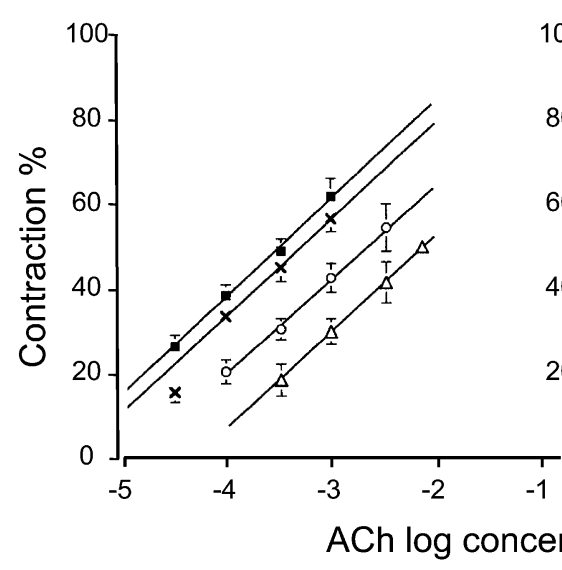

B

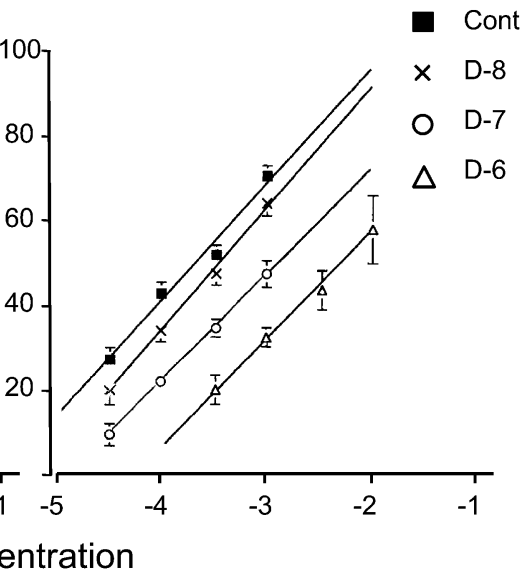

Fig. 4. Effect of M3 receptor antagonist on acetylcholine induced contractions. Responses of bladder strips from rats to increasing doses of acetylcholine $(\mathrm{ACh})$ in the presence of increasing concentrations of the M3 receptor antagonist darifenacin (D). Responses in male rats are illustrated in Panel A, female rats Panel B. The shift to the right, produced by Darifenacin, was similar in both. The response to $3 \times 10^{-2} \mathrm{M}$ ACh was taken as $100 \%$. Each point is the mean of averaged measurements from $n=4-5$ animals; bars represent SEM. Lines were drawn by least squares method.

phasic response in males but this only reached significance for the male and female rat $\alpha, \beta$-meth ATP data.

(iii) Dose response to $A C h$

The M2 receptor antagonist, methoctramine, had no effect on the response to ACh below $10^{-6}$ $\mathrm{M}$; at $10^{-5} \mathrm{M}$, responses were slightly reduced with a parallel shift to the right of the dose response, but this was not consistent.

The M3 receptor antagonist, darifenacin, shifted the dose response curves to the right at concentrations greater than $10^{-8} \mathrm{M}$ (rat data illustrated in Fig. 4). The shifts were similar for males and females of both species giving $\mathrm{pA}_{2}$ values of 7.79 (male rat), 7.81 (female rat), 7.76 (male guinea pig) and 8.36 (female guinea pig). As a control, atropine demonstrated high antagonist specificity with a $\mathrm{pA}_{2}$ value of 9.00 in the male rat strips. At the higher doses of darifenacin $\left(10^{-5}\right.$ M) the tissues became spontaneously active. Since large contractions were superimposed on the responses to high doses of $\mathrm{ACh}$ at these concentrations it was difficult to measure the upper and lower ends of the dose response curves. However, intermediate values indicated that the shifts were parallel suggesting that the antagonism was competitive.

\section{Discussion}

The aim of this study was to determine if there was any differences in the functional expression of muscarinic and purinergic receptors in the urinary bladder from males and females from 2 species, rat and guinea pig, under comparable experimental conditions. While we have shown that the phasic mechanical contractile response to nerve stimulation is greater in guinea pig 
than in rat, and in male guinea pigs when compared to female guinea pigs, overall, our data does not support any significant functional differences between the groups studied. We do however present novel data to suggest that the purinergic component of the nerve mediated phasic response is greater in males than in females, and that more than one purinoceptor subtype may be responsible for smooth muscle contraction in response to ATP in the rat bladder, providing potential focus for targeted pharmacological interventions.

Our results indicate that the tonic component of nerve-induced contraction and the acetylcholine response of bladder strips of rats and guinea pigs are antagonised by the M3 receptor antagonist, darifenacin, but not by the M2 receptor antagonist, methoctramine, correlating well with our RT-PCR results, and serving to confirm and extend results obtained previously that show M3 receptors produce contraction in the rat (Hegde et al., 1997; Matsui et al., 2000; Kories et al., 2003). We also demonstrated strong overall expression of the M2 receptor, which is in contrast to its lesser functional role. However, it has recently been demonstrated that in humans with neurogenic bladder dysfunction, a shift to functional M2 involvement occurs (Pontari et al., 2004), as has been described for hypertrophied rat bladder after denervation (Braverman et al., 1998b; Pontari et al., 2004). This suggests that M2 receptors are expressed, but while not functionally active under normal conditions, assume an important role in pathological states. The mechanisms that induce this functional shift are likely to be of clinical relevance and warrant further study.

From a methodological perspective, in the present experiments, isolated strips were used after removal of the urothelium and connective tissue. When the urothelium was present in control experiments, very high levels of P2X3 were detected. Functional responses and gene expression results were therefore presumed to result from receptors situated on the muscle itself, but they may also be on other structures within this layer such as motor nerves or interstitial cells (Hashitani et al., 2004). Further analysis of the gene products would be necessary to identify the exact location of receptor sites.

\section{Rat functional responses}

Rat tissue was more sensitive to applied ACh when compared to guinea pig. However, cholinergic contractile responses and their antagonism were similar in male and female rats with comparable $\mathrm{pA}_{2}$ values for darifenacin. A study by Kories et al (Kories et al., 2003) found a similar situation in human and rat tissue using $\mathrm{KCl}$ and carbachol challenge, and while it has been shown in $\mathrm{M} 3$ receptor knock-out mice that males, but not females, had difficulty urinating, the response of bladder strips were comparable (Matsui et al., 2000; Igawa et al., 2004). Differences between males and females might therefore be explained by urethral properties, as there are important sexual differences in the urethral muscles (Van der Werf and Creed, 2002).

The expression of mRNA for the muscarinic receptors was similar between the sexes in our study. Differential functional responses to carbachol have been documented in female rats during oestrus (Longhurst and Levendusky, 2000), and while we did not determine the oestrous phase of the female animals in our study, the work of others has shown that variation in M2 muscarinic receptor mRNA in the bladder of young $v$ s. old female rats was not attributable to cyclic serum oestradiol levels (Watanabe et al., 2008), suggesting that stage of cycle is not a major factor influencing muscarinic receptor mRNA expression. 
We saw consistent expression of mRNA for P2X1, P2X2, P2X4, P2X5 and P2X7 receptors in male and female rats. Primary expression of the P2X1 receptor is seen across the species, including humans (Lee et al., 2000; Vial and Evans, 2000; O'Reilly et al., 2001). For example in rats, P2X1 is the only subtype associated with the bladder detrusor smooth muscle membrane (Lee et al., 2000), and in P2X1 receptor deficient mice, ATP failed to evoke contraction or initiate inward currents (Vial and Evans, 2001). As PPNDS is one of the few sub-type specific antagonists for P2X purinoceptors that have been identified (Lambrecht $e t$ al., 2000), it was not possible to identify with certainty which receptors are responsible for the total components of the contraction in our study. The partial effect of PPNDS on the phasic contraction leads us to suggest that heteromeric complexes composed of the P2X1 receptor and another subtype are involved. This is in agreement with a recent study by Kennedy et al. (Kennedy et al., 2007), who used pyridoxalphosphate-6-azophenyl-2', 4'-disulphonic acid (PPADS) as an alternative P2X1 antagonist. In their study in guinea pig and mouse, PPADS inhibited but similarly did not abolish the noncholinergic component of neurogenic contractions. The authors suggest the possibility of a P2X1/ P2X4 heteromultimer (Kennedy et al., 2007). Future experiments, such as using PPNDS to inhibit $\alpha, \beta$-meth ATP responses (P2X1/P2X3) (North, 2002) will assist in defining this profile of receptor makeup. We also showed that the P2X7 receptor was consistently expressed in the rat tissue, however its specific expression in the nuclei of lamina propria and epithelial cells in both the rat and guinea pig, and not in the plasma membrane (Lee et al., 2000; Menzies et al., 2003) make it an unlikely contributor to the remaining ATP mediated contractile component.

Of note is our data indicating a greater purinergic contribution to the phasic nerve mediated response in male as compared to female rats. Our mRNA results indicated that some differences in expression of P2X3 and P2X6 exist between the sexes, with lower expression of both subtypes in the male animals. This warrants further investigation as a relatively greater purinergic component in males may underlie their decreased incidence of urge incontinence (Longhurst and Levendusky, 2000; Cheung et al., 2009).

\section{Guinea pig functional responses}

The contraction in response to nerve stimulation in guinea pig bladder strips was larger than for rat, and was closer in amplitude to the contraction to $\mathrm{ACh}$. However, the $\mathrm{pA}_{2}$ values for darifenacin were similar, and our gene expression studies showed that the M2 and M3 receptor subtypes again dominated. Further, we did not detect mRNA for M4 receptors in any of the guinea pig samples, and only detected M5 in the female animals. This compares with the findings in other species, where M2 and M3 receptors have been shown to be the predominant subtypes using both immunological and ligand binding techniques (Eglen et al., 1994; Wang et al., 1995).

There is previous evidence for species variation in purinergic responses, as we have shown that suramin is without action on strips from sheep bladder, but reduces nerve-induced responses in strips from rabbits (Creed et al., 1994). Furthermore, neither suramin nor PPADS ( $\mathrm{P}_{2}$-receptor antagonists) reduced the contraction to ATP in rat strips (Kageyama et al., 2000) but both inhibited contraction of guinea pig muscles (Hoyle et al., 1990; Usune et al., 1996). In the present experiments, PPNDS also had a greater effect on guinea pig than rat bladders. Again, until other specific antagonists are identified, it is not possible to determine which purinoceptors are involved 
but it is apparent that there are species differences.

In summary, these results indicate that muscarinic receptor subtypes M2 and M3 are present in bladder smooth muscle of males and females, and M3 is responsible for the tonic component of the nerve-mediated response in both species examined. In accord with our mRNA analysis, our functional studies suggest that the P2X1 receptor is not the only purinoceptor contributing to the phasic response, and the role of novel heteromeric complexes require further investigation. Finally, our data indicates that in male rats, a greater proportion of the phasic component of contraction is mediated by purinergic mechanisms. Given that the functional contribution of both muscarinic receptors and purinoceptors have been shown to change in unstable bladders, baseline data such as presented in this study will be critical in determining how relative functional contributions change in the diseased state, providing valuable information towards new treatment options.

\section{Acknowledgements}

The authors wish to thank Mr. Marcus Wolff, Dr. Allison Mladenovic and Mr. Stephen Callahan for technical assistance with the work undertaken in this study. Funding for the study was provided by Murdoch University.

\section{References}

Bayliss, M., Wu, C., Newgreen, D., Mundy, A.R. and Fry, C.H. (1999). A quantitative study of atropineresistant contractile responses in human detrusor smooth muscle, from stable, unstable and obstructed bladders. J. Urol. 162: 1833-1839.

Braverman, A.S., Kohn, I.J., Luthin, G.R. and Ruggieri, M.R. (1998a). Prejunctional $\mathrm{M}_{1}$ facilitory and $\mathrm{M}_{2}$ inhibitory muscarinic receptors mediate rat bladder contractility. Am. J. Physiol. 274: R517-R523.

Braverman, A.S., Luthin, G.R. and Ruggieri, M.R. (1998b). $\mathrm{M}_{2}$ muscarinic receptor contributes to contraction of the denervated rat urinary bladder. Am. J. Physiol. 275: R1654-R1660.

Burnstock, G. (2009). Purinergic cotransmission. Exp. Physiol. 94: 20-24.

Callahan, S.M. and Creed, K.E. (1986). Non-cholinergic neurotransmission and the effects of peptides on the urinary bladder of guinea-pigs and rabbits. J. Physiol. (Lond.) 374: 103-115.

Cheung, W.W., Khan, N.H., Choi, K.K., Bluth, M.H. and Vincent, M.T. (2009). Prevalence, evaluation and management of overactive bladder in primary care. BMC Fam. Pract. 10: 8.

Creed, K.E., Callahan, S.M. and Ito, Y. (1994). Excitatory neurotransmission in the mammalian bladder and the effects of suramin. Br. J. Urol. 74: 736-743.

Drescher, D.G., Upadhyay, S., Wilcox, E. and Fex, J. (1992). Analysis of muscarinic receptor subtypes in the mouse cochlea by means of the polymerase chain reaction. J. Neurochem. 59: 765-767.

Eglen, R.M., Hegde, S.S. and Watson, N. (1996). Muscarinic receptor subtypes and smooth muscle function. Pharmacol. Rev. 48: 531-565.

Eglen, R.M., Reddy, H., Watson, N. and Challiss, R.A. (1994). Muscarinic acetylcholine receptor subtypes in smooth muscle. Trends Pharmacol. Sci. 15: 114-119.

Hashitani, H., Yanai, Y. and Suzuki, H. (2004). Role of interstitial cells and gap junctions in the transmission of spontaneous $\mathrm{Ca}^{2+}$ signals in detrusor smooth muscles of the guinea-pig urinary bladder. $J$. Physiol. (Lond.) 559: 567-581.

Hegde, S.S., Choppin, A., Bonhaus, D., Briaud, S., Loeb, M., Moy, T.M., Loury, D. and Eglen, R.M. (1997). 
Functional role of $\mathrm{M}_{2}$ and $\mathrm{M}_{3}$ muscarinic receptors in the urinary bladder of rats in vitro and in vivo. Br. J. Pharmacol. 120: 1409-1418.

Hoyle, C.H., Knight, G.E.and Burnstock, G. (1990). Suramin antagonizes responses to $\mathrm{P}_{2}$-purinoceptor agonists and purinergic nerve stimulation in the guinea-pig urinary bladder and taenia coli. $\mathrm{Br}$. $J$. Pharmacol. 99: 617-621.

Igawa, Y., Zhang, X., Nishizawa, O., Umeda, M., Iwata, A., Taketo, M.M., Manabe, T., Matsui, M. and Andersson, K.E. (2004). Cystometric findings in mice lacking muscarinic $\mathrm{M}_{2}$ or $\mathrm{M}_{3}$ receptors. J. Urol. 172: 2460-2464.

Kageyama, S., Fujita, K., Suzuki, K., Shinbo, H., Masuda, N. and Uchida, W. (2000). Effect of age on the responses of rat bladder detrusor strips to adenosine triphosphate. BJU Int. 85: 899-904.

Kennedy, C., Tasker, P.N., Gallacher, G. and Westfall, T.D. (2007). Identification of atropine- and P2X receptor antagonist-resistant, neurogenic contractions of the urinary bladder. J. Neurosci. 27: 845851.

Khakh, B.S., Burnstock, G., Kennedy, C., King, B.F., North, R.A., Seguela, P., Voigt, M. and Humphrey, P.P. (2001). International union of pharmacology. XXIV. Current status of the nomenclature and properties of $\mathrm{P}_{2} \mathrm{X}$ receptors and their subunits. Pharmacol. Rev. 53: 107-118.

Kim, J.C., Yoo, J.S., Park, E.Y., Hong, S.H., Seo, S.I. and Hwang, T.K. (2008). Muscarinic and purinergic receptor expression in the urothelium of rats with detrusor overactivity induced by bladder outlet obstruction. BJU Int. 101: 371-375.

Kories, C., Czyborra, C., Fetscher, C., Schneider, T., Krege, S. and Michel, M.C. (2003). Gender comparison of muscarinic receptor expression and function in rat and human urinary bladder: differential regulation of $\mathrm{M}_{2}$ and $\mathrm{M}_{3}$ receptors? Naunyn Schmiedebergs Arch. Pharmacol. 367: 524531.

Lambrecht, G., Rettinger, J., Baumert, H.G., Czeche, S., Damer, S., Ganso, M., Hildebrandt, C., Niebel, B., Spatz-Kumbel, G., Schmalzing, G. and Mutschler, E. (2000). The novel pyridoxal-5'-phosphate derivative PPNDS potently antagonizes activation of $\mathrm{P}_{1} \mathrm{X}_{1}$ receptors. Eur. J. Pharmacol. 387: R19R21.

Lee, H.Y., Bardini, M. and Burnstock, G. (2000). Distribution of P2X receptors in the urinary bladder and the ureter of the rat. J. Urol. 163: 2002-2007.

Longhurst, P.A. and Levendusky, M. (2000). Influence of gender and the oestrous cycle on in vitro contractile responses of the rat urinary bladder to cholinergic stimulation. Br. J. Pharmacol. 131: 177-184.

Matsui, M., Motomura, D., Karasawa, H., Fujikawa, T., Jiang, J., Komiya, Y., Takahashi, S. and Taketo, M.M. (2000). Multiple functional defects in peripheral autonomic organs in mice lacking muscarinic acetylcholine receptor gene for the $\mathrm{M}_{3}$ subtype. Proc. Natl. Acad. Sci. U.S.A. 97: 95799584.

Menzies, J., Paul, A. and Kennedy, C. (2003). P2X ${ }_{7}$ subunit-like immunoreactivity in the nucleus of visceral smooth muscle cells of the guinea pig. Auton. Neurosci.: Basic Clin. 106: 103-109.

North, R.A. (2002). Molecular physiology of P2X receptors. Pharmacol. Rev. 82: 1013-1067.

O’Reilly, B.A., Kosaka, A.H., Chang, T.K., Ford, A.P., Popert, R. and McMahon, S.B. (2001). A quantitative analysis of purinoceptor expression in the bladders of patients with symptomatic outlet obstruction. BJU Int. 87: 617-622.

O'Reilly, B.A., Kosaka, A.H., Knight, G.F., Chang, T.K., Ford, A.P., Rymer, J.M., Popert, R., Burnstock, G. and McMahon, S.B. (2002). P2X receptors and their role in female idiopathic detrusor instability. J. Urol. 167: 157-164.

Phillips, J.K., McLean, A.J. and Hill, C.E. (1998). Receptors involved in nerve-mediated vasoconstriction in small arteries of the rat hepatic mesentery. Br. J. Pharmacol. 124: 1403-1412.

Phillips, J.K., Vidovic, M. and Hill, C.E. (1996). Alpha-adrenergic, neurokinin and muscarinic receptors in rat mesenteric artery; an mRNA study during postnatal development. Mech. Ageing Dev. 92: 235- 
246.

Pontari, M.A., Braverman, A.S. and Ruggieri, M.R., Sr. (2004). The $\mathrm{M}_{2}$ muscarinic receptor mediates in vitro bladder contractions from patients with neurogenic bladder dysfunction. Am. J. Physiol. 286: R874-R880.

Usune, S., Katsuragi, T. and Furukawa, T. (1996). Effects of PPADS and suramin on contractions and cytoplasmic $\mathrm{Ca}^{2+}$ changes evoked by $\mathrm{AP}_{4} \mathrm{~A}, \mathrm{ATP}$ and alpha, beta-methylene ATP in guinea-pig urinary bladder. Br. J. Pharmacol. 117: 698-702.

Van der Werf, B.A. and Creed, K.E. (2002). Mechanical properties and innervation of the smooth muscle layers of the urethra of greyhounds. BJU Int. 90: 588-595.

Vial, C. and Evans, R.J. (2000). P2X receptor expression in mouse urinary bladder and the requirement of $\mathrm{P}_{2} \mathrm{X}_{1}$ receptors for functional $\mathrm{P} 2 \mathrm{X}$ receptor responses in the mouse urinary bladder smooth muscle. Br. J. Pharmacol. 131: 1489-1495.

Vial, C.and Evans, R.J. (2001). Smooth muscle does not have a common P2X receptor phenotype: expression, ontogeny and function of $\mathrm{P}_{2} \mathrm{X}_{1}$ receptors in mouse ileum, bladder and reproductive systems. Auton. Neurosci. Basic Clin. 92: 56-64.

Wang, P., Luthin, G.R. and Ruggieri, M.R. (1995). Muscarinic acetylcholine receptor subtypes mediating urinary bladder contractility and coupling to GTP binding proteins. J. Pharmacol. Exp. Ther. 273: 959-966.

Watanabe, T., Matsumoto, M., Toji, S. and Miyagawa, I. (2008). Effects of estrogen on age-related changes in muscarinic responsiveness of the urinary bladder and lumbosacral dorsal root ganglion cells in female rats. Mol. Cell. Biochem. 318: 53-61. 